\title{
DIVERSITY AND ANTIMICROBIAL ACTIVITY OF LICHENS- ASSOCIATED ACTINOMYCETES IN CIBINONG SCIENCE CENTRE (CSC) AND CIBODAS BOTANICAL GARDEN (CBG) INDONESIA
}

\author{
Agustina Eko Susanti ${ }^{1 *}$, Shanti Ratnakomala ${ }^{2 * *}$, Wibowo Mangunwardoyo ${ }^{3 *}$ and Puspita \\ Lisdiyanti ${ }^{2 * *}$ \\ ${ }^{1}$ Postgraduate Student Department of Biology, Faculty of Mathematics and Natural Science \\ Universitas of Indonesia, Depok, 16424, Indonesia. \\ ${ }^{2}$ Research Center for Biotechnology, Indonesian Institute of Sciences \\ Jl. Raya Bogor Km. 46, Cibinong 16911, Indonesia \\ ${ }^{3}$ Department of Biology, Faculty of Mathematics and Natural Science \\ Universitas of Indonesia, Depok, 16424, Indonesia
}

\begin{abstract}
Bioprospecting has developed to all biological taxa including procaryotic. Actinomycetes become interesting procaryotic because of the ability to produce important secondary metabolite for human life. Actinomycetes are known as the largest antibiotic producer that has a broad range habitat. Some research has been done to find new antibiotic from the various habitat of actinomycetes. One of the interesting habitats of actinomycetes which never been explored in Indonesia is lichens... Lichens as the symbiotic structure of alga and fungi areknown as the ecological niche of various kinds of microorganisms including actinomycetes. Cibinong Science Centre (CSC) and Cibodas Botanical Garden (CBG) have various species of trees as the habitat of lichens. These areas are known as one of the research locations to explore the biodiversity of Indonesia. The aims of this research is to study the diversity and antimicrobial potency of actinomycetes isolated from 10 lichen samples with various type of thallus; crustose, fructose and foliose. Lichen samples were grown on the bark of 9 trees species in CSC and CBG. Isolation process used three agar media; HV, YIM6 and YIM711 with cycloheximide and nalidixic acid. Molecular identification based on 16S rRNA gene sequence. Antimicrobial activity was tested to 65 isolates by agar diffusion method to Bacillus subtilis BTCC B.612, Escherichia coli BTCC B.614, Candida albicans BTCC Y.33, Staphylococcus aureus BTCC B.611, Micrococcus luteus BTCC B.552. Isolation process retrieved 125 isolates with the highest number grow on HV agar medium. Based on the sample, the highest number of actinomycetes were isolated from crustose lichen attached on the bark of Averrhoea carambola. A total 69 isolates were identified as the genera Actinoplanes, Amycolatopsis, Angustibacter, Kribbella, Micromonospora, Mycobacterium, and Streptomyces. The screening process showed 24 isolates have antimicrobial activity, with the highest inhibitory activity against Micrococcus luteus BTCC B.552.
\end{abstract}

Keywords: Actinomycetes, Antimicrobial activity, Diversity, Identification 16S rRNA, Lichens

*Corresponding author:

Cibinong Science Center, Jl. Raya Bogor Km. 46, Cibinong 16911, Indonesia

Tel. +62-21-8754587, Fax. +62-21-87754588

E-mail. agustina.laz@gmail.com

\section{Introduction}

The pharmaceutical industry was implication of the bioprospecting development in humans life. Exploration various organisms as the drug sources has been developed to all biological taxa including procaryotic (Parrot $e t$ al., 2015). Ability of prokaryotic produce metabolite to inhibit the growth of pathogen microbes then explored as the source of new drugs. The discovery of new drugs in academics and laboratory level has traditionaly been focused on the exploitation of actinomycetes and filamentous fungi (Genniloud et al., 2011).

Actinomycetes are virtually unlimited source of novel compound with many therapeutic application and hold a prominent position due to their diversity and ability to produce novel bioactive compound 
(Subramani and Aalbersberg, 2012). These Gram-positive bacteria were reported able to produce antibacterial (Lazzarini et al., 2000; Liu et al., 2017), anticandidal (Charausova et al., 2016), antiparasitic (Pimentel-Elardo et al., 2010) and antiviral (Sacramento et al., 2004). The ability of actinomycetes as the highest producer of antibiotics from prokaryotes has been known for decades (Berdy, 2012). Two third of the world's antibiotics including the most important in medical treatment produce by actinomycetes in the genus of Streptomyces and Micromonospora (Kumar et al., 2010). This fact become one reason the research about actinomycetes keep doing recently to find new antibiotics compound.

Actinomycetes has the widest distribution among other bacteria in nature (Kumar et al., . 2010). It's broad habitat urged some research to find new compound through exploration of ecological niches that still rare to be explored. Invention of new source of actinomycetes being a good choice for pharmaciteucal development (Jiang et al., 2016). Some research reported successfully isolated actinomycetes from various rare habitat such as endosymbiont of plants (Nimnoi et al., 2009), extreme environmental (Tang et al., 2002; Okoro et al., 2009), and symbiosis of microorganisms such as lichens (Jiang et al., 2015; Parrot et al., 2015; Liu et al., 2017).

One source that interesting to be explored is lichens. Lichens are the symbiotic of alga/cyanobacteria and fungi (Liu et al., 2017). Even it is less commonly that lichens involved three or more partners (Nash, 2008). The structure of this organisms made it possible to produce thousands of bioactive compound (Jiang et al., 2015). Lichens also being habitat for various bacteria, that the roles in lytic activity was important to produce bioactive compound such as hormons or antibiotics to fulfill nitrogen requirement (Grube, 2009).

Research about diversity of lichensassociated actinomycetes confirmed that actinomycetes from tropic lichens more diverse than cold area (Gonzales et al., 2005). This report recently encourages studies about lichens-associated actinomycetes in some Asian countries such as Japan (Hamada et al., 2012) and China (Jiang et al., 2015; Liu et al., 2017). New species of actinomycetes was isolated from lichens such as Nocardioides exalbidus sp. nov. (Li et al., 2007) and Luteimicrobium album sp. nov. (Hamada et al.,
2012). Some actinomycetes isolated from lichens also reported has ability to inhibit the growth of another microorganisms and being potencial source for novel drugs development (Jiang et al., 2015).

Indonesia as one of tropical country has a very diverse wooden trees as the lichenes habitat. However, the study about lichenassociated actinomycetes from Indonesian was not reported. Therefore the aim of this study was to analyze the diversity and antimicrobial potency of lichen-associated actinomycetes from Indonesia. Some representative area with diverse wooden trees as lichens habitat located in west java; Cibinong Science Centre (CSC) which have 901 trees species (Noviady and Rivai 2015) and Cibodas Botanical Garden (CBG) which have 3,120 trees species (Rosyunita, 2017). This fact promising high diversity of actinomycetes that hopefully can be new source for potential antimicrobial compound to enrich bioprospecting in pharmaceutical.

\section{Materials and Methods}

\section{Study Area and Sampling of tree lichens}

This study was conducted from October 2017 to July 2018. Samples of lichens were various in thallus type and collected aseptically from the bark of tree in West Java Indonesia. Sampling sites were located in Cibinong Science Centre (CSC) with coordinate S. $6^{\circ} 29^{\prime} 49.7^{\prime \prime} ; \quad$ E. $106^{\circ} 50^{\prime} 45.3^{\prime \prime}$ and Cibodas Botanical Garden (CBG) with coordinate S. 644'22.1"; E. 10700'24.9". Total 5 samples of lichens were taken from 4 tree species in CSC; Cynometra cauliflora, Gnetum gnemon, Averrhoa carambola, Artocarpus integra (Figure 1a). Another 5 samples were taken from 5 tree species in CBG; Pandanus utilis, Magnolia sp., Brachychiton sp., Tristahiopsis taurina, and Cupresson torolusa (Figure 1b). Lichens samples were taken by sterile cutter and collected in sterile plastic bag. The rest process for this study was conducted in the Laboratory for Applied Microbiology, Indonesian Institute of Sciences.

\section{Isolation of Lichen-Associated Actinomycetes}

Each lichens sample was put in sterile microtubes. Each lichen samples $(0.1 \mathrm{~g})$ was put in the steril microtube, added by $1 \mathrm{ml}$ aquadest, then homogenized 3,000 rpm for 1 minute. The sample was centrifuged in 

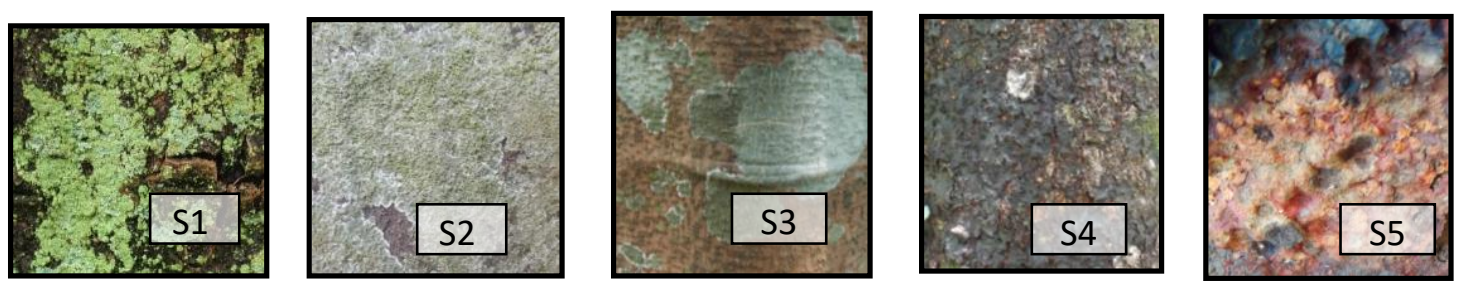

Figure 1a. Lichens from Cibinong Science Centre (CSC); S1: bark of Cynometra cauliflora, S2: bark of Gnetum gnemon, S3: bark of Averrhoa carambola, S4 and S5: bark of Artocarpus integra
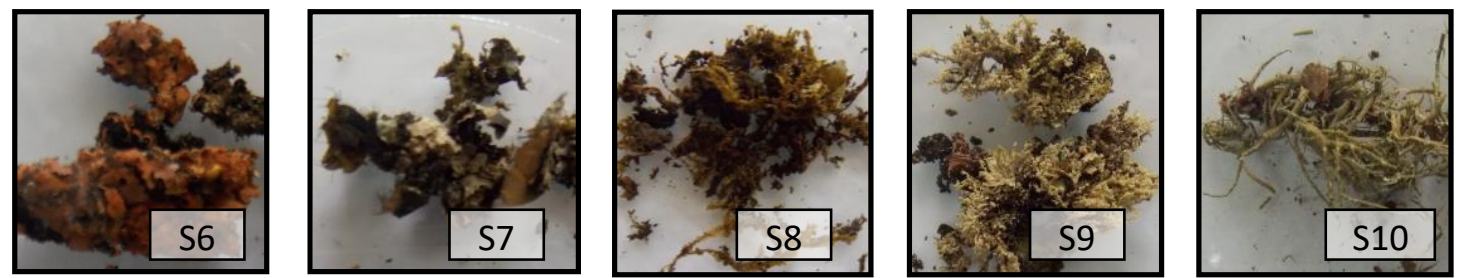

Figure 1b. Lichens from Cibodas Botanical Garden (CBG); S6: bark of Pandanus utilis, S7: Magnolia sp., S8: bark of Brachychiton sp., S9: bark of Tristahiopsis taurina, and S10: bark of Cupresson torolusa

13,000rpm for 5 minutes, the supernatan was then throwed out. This treatment was repeated for three times. Lichens was mashed in the sterile plastic with addition of $1 \mathrm{ml}$ aquadest. Mashed lichen $(1 \mathrm{ml})$ was mixed with $9 \mathrm{ml}$ aquadest as the first dilution. About $1 \mathrm{ml}$ from first dilution added with $9 \mathrm{ml}$ aquadest as the second dilution. Dilution process was done until $10^{-5}$. About $100 \mu$ l dilution mixture was then spread to each plate of isolation medium. This study was conduct with three kind of agar medium for isolation with the following ingredients per liter. HV agar: Humic acid $1 \mathrm{~g}$, $\mathrm{Na} 2 \mathrm{HPO} 40.5 \mathrm{~g}, \mathrm{KCl} 1.7 \mathrm{~g}, \mathrm{MgSO} 4.7 \mathrm{H} 2 \mathrm{O}$ $0.05 \mathrm{~g}, \mathrm{FeSO} 4.7 \mathrm{H} 2 \mathrm{O} 0.01 \mathrm{~g}, \mathrm{CaCl} 21 \mathrm{~g}, \mathrm{~B}-$ vitamins $(0.5 \mathrm{mg}$ each of thiamine- $\mathrm{HCl}$, riboflavin, Niacin, pyridoxin, Capantothenate, inositol, p-aminobenzoic acid, and $0.25 \mathrm{mg}$ of biotin), agar $18 \mathrm{~g}$, water $1000 \mathrm{ml}, \mathrm{pH} 7.4$ (Hayakawa, 2008).

YIM 6: soluble starch $10 \mathrm{~g}$, casein $0.3 \mathrm{~g}$, $\mathrm{KNO} 32 \mathrm{~g}, \mathrm{MgSO} 4 \cdot 7 \mathrm{H} 2 \mathrm{O} 0.05 \mathrm{~g}, \mathrm{NaCl} 2 \mathrm{~g}$, $\mathrm{K} 2 \mathrm{HPO} 42 \mathrm{~g}$, CaCO $30.02 \mathrm{~g}$, FeSO 4 10mg, Vit mixture of $\mathrm{HV}$ medium $3.7 \mathrm{mg}$, agar $15 \mathrm{~g}$. $\mathrm{pH}$ 7.2. YIM 711: Casein 1.5g, soybean peptone $0.5 \mathrm{~g}, \mathrm{~K} 2 \mathrm{HPO} 4 \cdot \mathrm{H} 2 \mathrm{O} 1 \mathrm{~g}, \mathrm{MgSO} 4 \cdot 7 \mathrm{H} 2 \mathrm{O} 0.5 \mathrm{~g}$, $\mathrm{CaCO} 30.3 \mathrm{~g}, \mathrm{NaCl} 5 \mathrm{~g}$, Vit mixture of $\mathrm{HV}$ medium $3.7 \mathrm{mg}$, agar $15 \mathrm{~g}$. pH 7.5 (Jiang et al., 2015).

All the medium added by $50 \mathrm{mg}$ cycloheximide and $50 \mathrm{mg}$ as fungi inhibitor and $40 \mathrm{mg}$ nalidixic acid as the Gram-negative bacteria inhibitor (in liter). Lichens samples from CSC was diluted for $10^{-3}, 10^{-4}, 10^{-5}$. While samples from CBG used dilution 10-1, $10^{-2}$ to coat YIM 6 and YIM 711, dilution $10^{-2}$,
$10^{-3}$ on $\mathrm{HV}$ agar media. Cultivation was done in $30{ }^{\circ} \mathrm{C}$ for $7-21$ days. The colony was observed under the microscope with 10 times magnificient. A single actinomycetes colony was isolated to yeast extract-malt extract agar (ISP-2) medium. The pure strain were conserved in $20 \%$ of glycerol at $-80{ }^{\circ} \mathrm{C}$ (Jiang et al., 2015; Liu et al., 2017).

\section{Extraction of Genomic DNA}

One ose pure strain on ISP-2 agar was cultured into 5 Tryptic Soy Broth (TSB) (Axenov-Gibanov, 2016). About $1 \mathrm{ml}$ culture was put into microtube and centrifuged on $13000 \mathrm{rpm}$ for 5 minutes. The supernatan was throw out, and the sedimen used for DNA extraction. DNA pellet washed by TE-buffer then centrifuged at 13,000 rpm for 5 minutes, this step was done twice. The cleaned sedimen added by $300 \mu \mathrm{l}$ buffer extraction added to, mashed the pellet then warm up in $60^{\circ} \mathrm{C}$ water bath for 10 minutes. The sedimen was then cold in room temperature $25{ }^{\circ} \mathrm{C}$ and added 150 $\mu 1$ sodium asetat. The mixture was put in room temperature for 10 minutes and centrifuged $13,000 \mathrm{rpm}$ for 5 minutes. Supernatan was taken and added by isopropanol with ratio $1: 1$, centrifuged 13,000 for 10 minutes to get DNA extract. The DNA washed by $500 \mu \mathrm{l}$ etanol and added by TE buffer $50 \mu \mathrm{l}$ (Ratnakomala, 2016).

\section{Amplification of 16S rRNA}

The 16SrRNA gene was amplified by mixed $1 \mu \mathrm{L}$ isolate DNA in measured concentration, with $2 \mu \mathrm{L}$ PCR mixture that 
consists of $\mathrm{HS}$ ready mix, $\mathrm{ddH}_{2} \mathrm{O}$, and forward primer 9F and reverse 1541R 9F (forward: 5'GAGTTTGATCCTGGCTCAG-3' position 9-27) and 1541R (Reverse: 5'-AAGGAGGTG ATCCAGCC3' position 1541-1525) with concentration 20 pmol. Thermal cycling using the following procedure: Denaturation $96^{\circ} \mathrm{C}$ for 5 minutes, followed by 30 cycles denaturation $96^{\circ} \mathrm{C}$ for 30 seconds, annealing at $55^{\circ} \mathrm{C}$ for 30 seconds, extension at $72{ }^{\circ} \mathrm{C}$ for 7 minutes (Widyastuti and Ando 2010). Visualization PCR product on agarose 1\%, under UV transilluminator. The PCR product then used in sequenceing process using BigDye Terminator Version 3.1 Cycle Sequencing Kit. Sequencing Product analyzed by DNA Sequencer ABI Prism 3700 (Applied Biosystem) by the factory protocol. Sequencing product edited using bioedit and confirmed online by ez-Taxon server. Phylogenetic trees based on the 16S rRNA (Kim et al., 2012) gene sequences were generated using the neighbor-joining method from the software package MEGAversion 6.0 (Tamura et al., 2013).

\section{Determination Antimicrobial Activity}

The pure strains on ISP-2 agar was screened by agar diffusion method against bacteria and yeast to determined it's antimicrobial potency. The microbial that were used as indicator for the test consist of three Gram positives bacteria: Bacillus subtilis BTCC B-612, Micrococcus luteus BTCC B552, Streptococcus aureus BTCC B-611, Gram negative bacteria Escherichia coli BTCC B-614 and fungi Candida albicans BTCC Y-33. The tested bacterial were cultured in Nutrient Broth (NB) and Candida cultured in Potato Dextrose Broth (PDB) medium for 24 hours. The $9 \mathrm{~mm}$ pure strains of actinomycetes was taken put on the surface of soft layer agar after drain up, and incubated in optimum temperature of each microbial tested for 18-24 hours (Ratnakomala et al., 2016a). The inhibition zone was measured in scale.

\section{Results}

\section{Lichen sample}

This research used lichens as the source of actinomycetes. Lichens are the symbiotic organisms, usually composed fungal as mycobiont and one or more photosynthetic partner such as green alga or cyanobacterium as photobiont (Nash, 2008). Lichen-associated microbial communities consist of diverse taxonomic in group. Various bacterial genera found in lichens led to speculation of their different role to support life of lichens. Bacteria can be involved in defense against lichens pathogens and feeders. Davies et al., . 2005 reported that lichen-associated actinomycetes showing to be potent antibiotics at very low concentration. This result also suggests that low-abundance strain could play significant roles in the lichen micro-ecosystem (Grube and Berg, 2009).

Lichens sample in this research has three kinds of thallus type; crustose, fruticose, and foliose. Based on Hale (1979), sample 1, 2, 3, 5 and 6 belong to crustose lichens. These lichens have a fairly thick thallus but the margins are unlobed and sometimes fade into the substrate and become indistinct. Removal process from the bark must destroy the thallus. Sample 8, 9, and 10 belong to fruticose lichens, with bushy and hairy thallus attached to the tree bark. Sample 4 and 7 belongs to foliose lichen, the thallus growth outward from the and becoming round at outline part.

\section{Medium and Isolation Effectiveness}

Isolation was conducted for 10 lichens sample from 9 trees from area of Cibinong Science Centre (CSC) and Cibodas Botanical Garden (CBG) West Java with spread dilution method. Sample 1 to 5 were from CSC area (in blue graph), while sample 6 to 10 were from CBG (in red graph). Dilution for lichens from CSC was conducted from $10^{-3}$ until $10^{-5}$, and samples from CBG used dilution $10^{-1}$ until $10^{-}$ ${ }^{3}$. Totally 125 isolates were collected from the isolation process. Each sample resulted various numbers of isolates (Figure 2). Total actinomycetes isolated from CSC sample was 97 isolates and from CBG sample was 28 isolates.

Most isolates resulted from sample 3, crustose lichen from the bark of Averhoea carambolla (32 isolates) followed by sample 5 crustose lichen from the bark of Artocarpus integra (26 isolates) and sample 8 fruticose from the bark of Brachychiton sp. (21 isolates). A $62 \%$ isolates resulted from crustose lichen, since most of samples (5 of 10) has crustose thallus. Compare to research conducted by Liu et al., (2017), most isolates 
(67\%) resulted from foliose lichen. This research used 23 foliose from 35 lichen sample. Both research showed that the isolates number didn't affected by type of lichen as the samples.

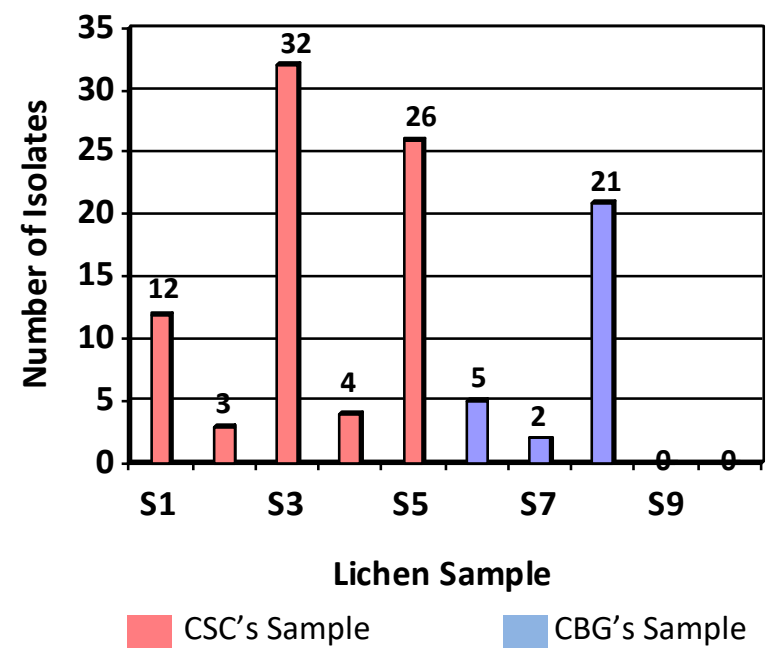

Figure 2. Number of Isolates Based on Lichens Samples

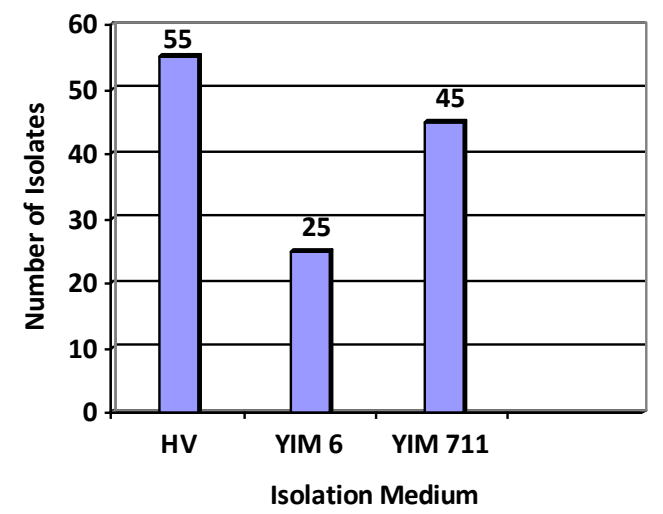

Figure 3. Number of Selected Isolates Based on Morphological character

Three kinds of agar medium were used in isolation process; HV, YIM 6, and YIM 711 medium. Starch-casein medium (YIM 6) and Casein Soybean peptone medium (YIM 711) was designed as the isolation medium foractinomycetes from several habitats. One kind of actinomycetes that can use YIM 6 and YIM 711 was lichens-associated actinomycetes. The design of YIM 6 and YIM 711 for lichen-associated actinomycetes isolation proces based on some factors, such as isolation goals, medium component, and inhibitors. The component (carbon and nitrogen sources) of selective isolation media was formulated by using information from taxonomic databases and phenotypic databases of actinomycetes as the isolation target (Jiang et al., 2016).

The Humic acid-Vitamins (HV) agar contain soil humic acid as carbon and nitrogen source. The humic reserve of soils are thought to represent several times the total organic carbon in living organisms; and more than half of the total organic carbon in soils. The occurence of carboxyl and hidroxyl groups on the periphery of humic macro molecules plays a major roles by facilitating the formation of mineral ions or small organic molecules. Humic acid generally are resistant to biological decomposition. However, actinomycetes have been shown capable of utilizing the humic acid. Its implicate HV agar as the efficient and adequate medium of growth for Streptomycetes and various rareactinomycetes, while restricting growth of non-filamentous bacteria colonies (Dari et al., 2008; Hayakawa, 2008).

\section{Diversity of Actinomycetes from lichen}

A 125 isolates of actinomycetes resulted from 10 lichen samples. Morphological observation showed most of isolates posses the Streptomyces genera with characteristics; slow growing, aerobic, glabrous, or chalky, heaped, folded and have different collor of aerial and substrat mycelia. Some of isolates with the certain character also resulted earthy oddor (Suneetha et al., 2011).

Contamination by fungi became the problem in the isolation process, so that only 69 isolates can be molecularly identified and 65 isolates were screened for the antimicrobial activities. The 69 isolates of actinomycetes were identified based on 16S rRNA and confirmed to ez-Taxon to closest species and genus level (Table 1). Cultivation of isolates in in Tryptic Soy Broth (TSB) was conducted to get DNA extract of actinomycetes. Molecular identification showed that 69 isolates belong to 7 genera; Actinoplanes, Amycolatopsis, Angustibacter, Kribbella, Micromonospora, Mycobacterium, and Streptomyces. The 87\% of isolates belongs to Streptomyces with 23 closests species, followed by $4.3 \%$ Micromonospora, 2.9\% Kribbella and each $1.4 \%$ for Actinoplanes, Amycolatopsis and Mycobacterium. All identified genera also found in lichen from Yunan provinces China (Jiang et al., 2015; Liu et al., 2017). Based on molecular identification, most genera isolated 
from Cibinong Science Centre (CSC) and Cibodas Botanical Garden (CBG) belongs to Streptomyces. This genera successfully isolated using all kind of agar medium in this research. Streptomyces was the dominant genus consits of almost 600 species (Kampfer et al., 2008). Actinoplanes, Angustibacter, and Mycobacterium were isolated using HV. Kribbella and Angustibacter were isolated using YIM 6, while Mycobacterium was isolated using YIM 711.

Table 1. Identification of Lichens-Associated Actinomycetes based on 16S rRNA gene similarity

\begin{tabular}{|c|c|c|c|c|c|}
\hline No & Isolate & Genus & Scientific Name & $\begin{array}{c}\text { Lichen } \\
\text { Sample } \\
\end{array}$ & BLAST Identity \\
\hline 1 & LC-1 & Micromonospora & Micromonospora chersina & S1 & $1388 / 1389(99,93 \%)$ \\
\hline 2 & LC-2 & Streptomyces & Streptomyces seoulensis & S1 & $1413 / 1416(99,79 \%)$ \\
\hline 3 & L C-3 & Streptomyces & Streptomyces violacerubidus & $\mathrm{S} 1$ & $1418 / 1437(98,66 \%)$ \\
\hline 4 & LC-4 & Streptomyces & Streptomyces kunmingensis & S1 & $1419 / 1428(99,36 \%)$ \\
\hline 5 & LC-5 & Actinoplanes & Actinoplanes couchii & S1 & $1370 / 1371(98,90 \%)$ \\
\hline 6 & LC-6 & Streptomyces & Streptomyces kunmingensis & S1 & $1089 / 1095(99,45 \%)$ \\
\hline 7 & LC-8 & Streptomyces & Streptomyces kunmingensis & S1 & $1407 / 1415(99,43 \%)$ \\
\hline 8 & LC-9 & Streptomyces & Streptomyces kunmingensis & S1 & $1406 / 1416(99,29 \%)$ \\
\hline 9 & LC-10 & Streptomyces & Streptomyces thermoviolaceous & S1 & $1404 / 1426(98,43 \%)$ \\
\hline 10 & LC-11 & Micromonospora & Micromonospora schwarzwaldensis & S2 & $1415 / 1422(99,50 \%)$ \\
\hline 11 & LC-13 & Micromonospora & Micromonospora schwarzwaldensis & S2 & $1404 / 1410(99,57 \%)$ \\
\hline 12 & LC-14 & Streptomyces & Streptomyces seoulensis & S3 & $1412 / 1413(99,93 \%)$ \\
\hline 13 & LC-15 & Streptomyces & Streptomyces cinerochromogenes & S3 & $1414 / 1429(98,94 \%)$ \\
\hline 14 & LC-16 & Streptomyces & Streptomyces seoulensis & S3 & $1464 / 1613(90,72 \%)$ \\
\hline 15 & LC-17 & Angustibacter & Angustibacter luteus & S3 & $1414 / 1428(99,01 \%)$ \\
\hline 16 & LC-19 & Streptomyces & Streptomyces cinerochromogenes & S3 & $1410 / 1428(98,72 \%)$ \\
\hline 17 & LC-21 & Streptomyces & Streptomyces similanensis & S3 & $1476 / 1507(97,94 \%)$ \\
\hline 18 & LC-22 & Streptomyces & Streptomyces collinus & S3 & $1409 / 1420(99,22 \%)$ \\
\hline 19 & LC-23 & Streptomyces & Streptomyces palmae & S3 & $1408 / 1429(98,51 \%)$ \\
\hline 20 & LC-25 & Streptomyces & Streptomyces collinus & S3 & $1411 / 1421(99,29 \%)$ \\
\hline 21 & LC-26 & Streptomyces & Streptomyces seoulensis & S3 & $1403 / 1422(98,65 \%)$ \\
\hline 22 & LC-27 & Streptomyces & Streptomyces seoulensis & S3 & $1411 / 1413(99,86 \%)$ \\
\hline 23 & LC-28 & Streptomyces & Streptomyces thermoviolaceus & S3 & $1410 / 1412(99,86 \%)$ \\
\hline 24 & LC-31 & Streptomyces & Streptomyces cinerochromogenes & S3 & $1430 / 1445(98,94 \%)$ \\
\hline 25 & LC-35 & Streptomyces & Streptomyces rochei & S3 & $1418 / 1428(99.30 \%)$ \\
\hline 26 & LC-36 & Streptomyces & Streptomyces badius & S3 & $1411 / 1413(99.86 \%)$ \\
\hline 27 & LC-37 & Streptomyces & Streptomyces palmae & S3 & $1434 / 1453(98.67 \%)$ \\
\hline 28 & LC-40 & Streptomyces & Streptomyces collinus & S3 & $1423 / 1432(99.37 \%)$ \\
\hline 29 & LC-41 & Streptomyces & Streptomyces lomordensis & S4 & $1426 / 1433(99.51 \%)$ \\
\hline 30 & LC-44 & Streptomyces & Streptomyces roseolus & S4 & $1403 / 1412(99.36 \%)$ \\
\hline 31 & LC-47 & Streptomyces & Streptomyces cinereoruber & S4 & $1414 / 1419(99.65 \%)$ \\
\hline 32 & LC-50 & Kribella & Kribella aluminosa & S4 & $1394 / 1407(99.07 \%)$ \\
\hline 33 & LC-51 & Streptomyces & Streptomyces atriruber & S4 & $1414 / 1424(99.22 \%)$ \\
\hline 34 & LC-52 & Streptomyces & Streptomyces atriruber & S4 & $1424 / 1436(99.15 \%)$ \\
\hline 35 & LC-56 & Kribella & Kribella karoonensis & S4 & $1422 / 1441(98.65 \%)$ \\
\hline 36 & LC-57 & Streptomyces & Streptomyces roseolus & S4 & $1419 / 1428(99.36 \%)$ \\
\hline 37 & LC-58 & Streptomyces & Streptomyces puniceus & S4 & $1424 / 1425(99.93 \%)$ \\
\hline 38 & LC-60 & Streptomyces & Streptomyces puniceus & S4 & $1448 / 1449(99.93 \%)$ \\
\hline 39 & LC-66 & Streptomyces & Streptomyces puniceus & S5 & $1424 / 1425(99.93 \%)$ \\
\hline 40 & LC-67 & Streptomyces & Streptomyces seoulensis & S5 & $1426 / 1427(99.93 \%)$ \\
\hline 41 & LC-68 & Streptomyces & Streptomyces violacerubdius & S5 & $1421 / 1441(98.58 \%)$ \\
\hline 42 & LC-69 & Streptomyces & Streptomyces coerulescens & S5 & $1407 / 1411(99.50 \%)$ \\
\hline 43 & LC-71 & Streptomyces & Streptomyces althioticus & S5 & $1421 / 1423(99.86 \%)$ \\
\hline 44 & LC-73 & Streptomyces & Streptomyces althioticus & S5 & $1430 / 1432(99.86 \%)$ \\
\hline 45 & LC-74 & Streptomyces & Streptomycesrhizosphaerihabitans & S5 & $1429 / 1439(99.30 \%)$ \\
\hline 46 & LC-76 & Amycolatopsis & Amycolaptosis rubida & S5 & $1412 / 1430(98.72 \%)$ \\
\hline 47 & LC-77 & Streptomyces & Streptomyces seoulensis & S5 & $1428 / 1431(99.79 \%)$ \\
\hline 48 & LC-78 & Streptomyces & Streptomyces palmae & S5 & $1421 / 1441(98.59 \%)$ \\
\hline 49 & LC-79 & Streptomyces & Streptomyces seoulensis & S5 & $1412 / 1415(99.79 \%)$ \\
\hline 50 & LC-80 & Streptomyces & Streptomyces violacerobidus & S5 & $1426 / 1446(98.59 \%)$ \\
\hline 51 & LC-81 & Streptomyces & Streptomyces violaceorectus & S5 & $1424 / 1433(99.37 \%)$ \\
\hline 52 & LC- 82 & Streptomyces & Streptomyces fragilis & S5 & $1414 / 1421(99.50 \%)$ \\
\hline 53 & LC-83 & Streptomyces & Streptomyces collinus & S5 & $1409 / 1418(99.36 \%)$ \\
\hline 54 & LC-84 & Streptomyces & Streptomyces collinus & S5 & $1410 / 1420(99.29 \%)$ \\
\hline 55 & LC-86 & Streptomyces & Streptomyces seoulensis & S5 & $141 / 1413(99.86 \%)$ \\
\hline
\end{tabular}




\begin{tabular}{|c|c|c|c|c|c|}
\hline 56 & LC-87 & Streptomyces & Streptomyces aureus & S6 & $14181419(99.89 \%)$ \\
\hline 57 & LC-88 & Streptomyces & Streptomyces collinus & S5 & $1413 / 1422(99.36 \%)$ \\
\hline 58 & LC-89 & Streptomyces & Streptomyces seoulensis & S6 & $1427 / 1428(99.93 \%)$ \\
\hline 59 & LC-94 & Streptomyces & Streptomyces caniferus & S8 & $1409 / 1411(99.86 \%)$ \\
\hline 60 & LC-96 & Streptomyces & Streptomyces seoulensis & S8 & $1418 / 1420(99.86 \%)$ \\
\hline 61 & LC-100 & Streptomyces & Streptomyces camponoticapitis & S8 & $1389 / 1394(99.64 \%)$ \\
\hline 62 & LC-103 & Streptomyces & Streptomyces aureus & S8 & $1426 / 1428(99.86 \%)$ \\
\hline 63 & LC-109 & Streptomyces & Streptomyces collinus & S8 & $1418 / 1427(99.36 \%)$ \\
\hline 64 & $\begin{array}{l}\text { LC-110 } \\
\text { Continue.. }\end{array}$ & Streptomyces & Streptomyces seoulensis & S8 & $1416 / 1417(99.93 \%$ \\
\hline$\overline{65}$ & LC-111 & Streptomyces & Streptomyces seoulensis & S5 & $1407 / 1408(99.93 \%)$ \\
\hline 66 & LC-112 & Streptomyces & Streptomyces cinerochromogenes & S3 & $1422 / 1439(98.80 \%)$ \\
\hline 67 & LC-118 & Streptomyces & Streptomyces palmae & $\mathrm{S} 3$ & $1433 / 1427(97.32 \%)$ \\
\hline 68 & LC-122 & Mycobacterium & Micobacterium neworleanense & S8 & $1434 / 1453(98.66 \%)$ \\
\hline 69 & LC-125 & Streptomyces & Streptomyces kunmingensis & S1 & $1416 / 1423(99.50 \%)$ \\
\hline
\end{tabular}

Based on data in Table 1, each lichen samples resulted various genus and species. Sample 1, the crustose lichen from the bark of Cynometra cauliflora has the most diverse genus of actinomycetes. Three genus were isolated from this lichen; Actinoplanes, Micromonospora, and Streptomyces. Two genus; Angustibacter and Streptomyces were isolated from sample 3, the crustose lichens of Averhoea carambola. Genus Kribbella and Streptomyces isolated from sample 4, foliose lichens of Artocarpus integra. Genus Amicolaptosis and Streptomyces isolated from sample 5, crustose lichen of Artocarpus integra. Genus Mycobacterium and Streptomyces isolated from sample 8, fruticose lichen of Brachychiton sp. Sample 2 and 6 consists of only one genus.

The most diverse species of actinomycetes belongs to sample 5, crustose lichens of Artocarpus integra. This lichen consist of 10 closest species. This result followed by sample 3 (crustose lichens of Averhoea carambola) and sample 4 (foliose lichens of Artocarpus integra) with 9 and 8 species of each. This result showed that the most diverse actinomycetes did not belong to any kind of lichen thallus.

\section{Antimicrobial Activity of Lichens Associated Actinomycetes}

Determination of antimicrobial activity was conducted by agar plug diffusion method toward 65 isolates. Antimicrobial activity showed by 24 isolates to at least one tested microbial (Table 2). Fifteen isolates were able to inhibit the growth of Bacillus subtilis and Micrococcus luteus, and 6 isolates were inhibit Staphylococcus aureus. Two isolates were able to inhibit the growth of Candida albicans, and only one isolate inhibited the growth of
Escherichia coli. Most inhibition zones were formed against Gram-positive bacteria; Bacillus subtilis, Micrococcus luteus and Staphylococcus aureus compare to Gramnegative bacteria (Escherichia coli). This result because the differences in cell wall constituent and arrangement between Grampositive and Gram-negative bacteria. Gram positive bacteria cell walls contain peptidoglycan layer, an ineffective permeability barrier (Pratiwi, et al., 2016). The outer membrane of Gram negative bacteria contain lipopolysaccharide component an effective barrier against hydrophobic substances.Antimicrobial activity against Candida albicans as Eukaryotes cell also lower than Gram-positive bacteria, because organelles of this organism protected by membrane-enclosed nucleus and DNA that make the cell structucally more complex than prokaryotes (Madigan et al., 2012).

The isolates LC-23, LC-94, and LC-100 (figure 4) screening result showed were able to inhibit at least three microbial tested. Isolate LC-23 able to inhibit all of Gram-positive bacteria. It has potency as anti Gram-positive bacteria. Isolate LC-94 was able to inhibit all Gram-positive bacteria and fungi Candida albicans. It was potential as anti Gram-positive bacteria and anti-candida. Isolates LC-100 was able to inhibit the growth of all bacteria belongs to Gram positive and Gram negative. This isolate was potential as broad spectrum antibiotics. 
Table 2. Inhibition zone diameters of 24 isolates of lichen-associated Actinomycetes (coloni diameters around $5 \mathrm{~mm}$ ) against tested microorganisms.

\begin{tabular}{|c|c|c|c|c|c|c|}
\hline \multirow[t]{2}{*}{ No } & \multirow[t]{2}{*}{ Isolates } & \multicolumn{5}{|c|}{ Diameter Inhibition Zone (mm) } \\
\hline & & $\begin{array}{c}\text { B. } \\
\text { subtilis }\end{array}$ & $\begin{array}{c}\text { M. } \\
\text { luteus }\end{array}$ & $\begin{array}{c}S . \\
\text { aureus }\end{array}$ & $\begin{array}{c}E . \\
\text { coli }\end{array}$ & $\begin{array}{c}C . \\
\text { albicans }\end{array}$ \\
\hline $\mathbf{1}$ & LC-2 & 16,0 & 20.0 & & & \\
\hline 2 & LC-6 & & 12.0 & & & \\
\hline 3 & LC-8 & 17.0 & 25.0 & & & \\
\hline 4 & LC-15 & 11.2 & & & & \\
\hline 5 & LC-23 & 21.0 & 23.0 & 22.5 & & \\
\hline 6 & LC-28 & 11.0 & & & & \\
\hline 7 & LC-29 & & & 12.7 & & \\
\hline 8 & LC-32 & & & 11.5 & & \\
\hline 9 & LC-36 & 13.0 & & & & \\
\hline 10 & LC-37 & 20.0 & 16.0 & & & \\
\hline 11 & LC-41 & 10.0 & & & & \\
\hline 12 & LC-46 & & 23.0 & & & \\
\hline 13 & LC-49 & 10.0 & 19.0 & & & \\
\hline 14 & LC-51 & 8.0 & 20.0 & & & \\
\hline 15 & LC-52 & & 19.0 & & & \\
\hline 16 & LC-58 & 10.0 & 11.0 & & & \\
\hline 17 & LC-74 & & & & & 10.8 \\
\hline 18 & LC-75 & 9.0 & & & & \\
\hline 19 & LC-84 & & & 12.0 & & \\
\hline 20 & LC-86 & & 8.55 & & & \\
\hline 21 & LC-94 & 8.8 & 8.5 & 10.0 & & 14.3 \\
\hline 22 & LC-100 & 22.8 & 26.8 & 23.3 & 17.4 & \\
\hline 23 & LC-105 & & 8.5 & & & \\
\hline 24 & LC- 115 & 20.7 & 19.0 & & & \\
\hline & Total isolat & 15 & 15 & 6 & 1 & 2 \\
\hline
\end{tabular}

\section{Characteristic of Isolate LC-23, LC-94, and LC-100}

Sequence data of isolates LC-23, LC-94, and LC-100 has been submited to gene bank of NCBI. The accession number for sequence LC-23 was SUB5611109 LC-23 MK910204, accession number for sequence LC-94 was SUB5610932 Streptomyces.MK910159, and accession number for sequence LC-100 was SUB5595872 Streptomyces MK898926.

Molecular identification of 16S rRNA gene conducted to the three isolates showed that LC-23 has $98.51 \%$ similarity to Streptomyces palmae isolated from rhizosphere of oil palm (Elaeis guineensis Jacq.). This closests Streptomyces has 21 different bases over 1408 total basephare analyze. Streptomyces palmae reported has grey to light brown mycelium color and showed antifungal activity (Sujarit $e t$ al., 2016). Isolates LC-23 showed white aerial mycelium and able to change ISP 2 medium into yellow. Isolate LC-94 has $99.86 \%$ similarity to Streptomyces caniferus with difference 2 bases over 1409 base analysed. Streptomyces caniferus has white color in ISP
2 and grey in ISP 3 to ISP 7 (Strain, 1986), it used to be isolated from polychaeta Filograna sp.and has antifungal against Candida albicans and cytotoxic activity against A549 human lung carcinoma cells, MDA-MB-231 human breast adenocarcinoma cells and HT29 human colorectal carcinoma cells (Perez et al., 2016). Isolate LC-94 also has antifungal activity against Candida albicans, showed grey color on ISP 2 and not able to change medium color. Isolates LC-100 has $99.64 \%$ similarity to Streptomyces camponoticapitis with 5 bases difference over 1388 base analyzed. Streptomyces camponoticapitis isolated from the head of ant Camponotus japonicus Mayr showed varies mycelium from colorless to moderate yellow (Li et al., 2016). Isolate LC100 showed white aerial mycelium on ISP 2 and not able to change the medium color.

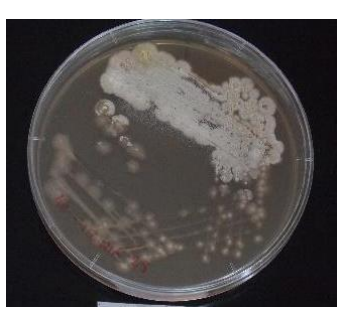

LC-23

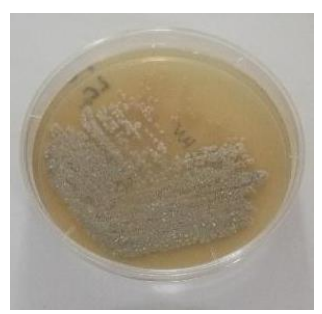

LC-94

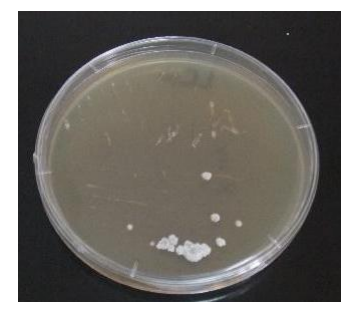

LC-100

Figure 4. Top Surface Appearence of the isolate LC-23, LC-94, and LC-100 on ISP 2 Agar Medium

Neighbor joining method of phylogenetic tree analyze was constructed to explain taxonomical position of isolates LC-23, LC94, and LC-100 compared to their type strain in genus Streptomyces (Figure 5). Sequence of Aquifex phyrophlus Ko15a used as the outgroup in the phylogenetic tree. Numbers at nodes are bootstrap values based on 1000 resamplings.

Result analyse of phylogenetic tree showed that the closest species of tree isolate differ from 16S rRNA analyze. Closest species of isolate LC-94 was Streptomyces glebosus with the similar value $99.78 \%$, while for isolate LC100 the closest species was Streptomyces 
niveus with similar value $99.56 \%$. The interesting result showed by LC-23 which showed distinc phyletic line with other type strain in Streptomyces genera.

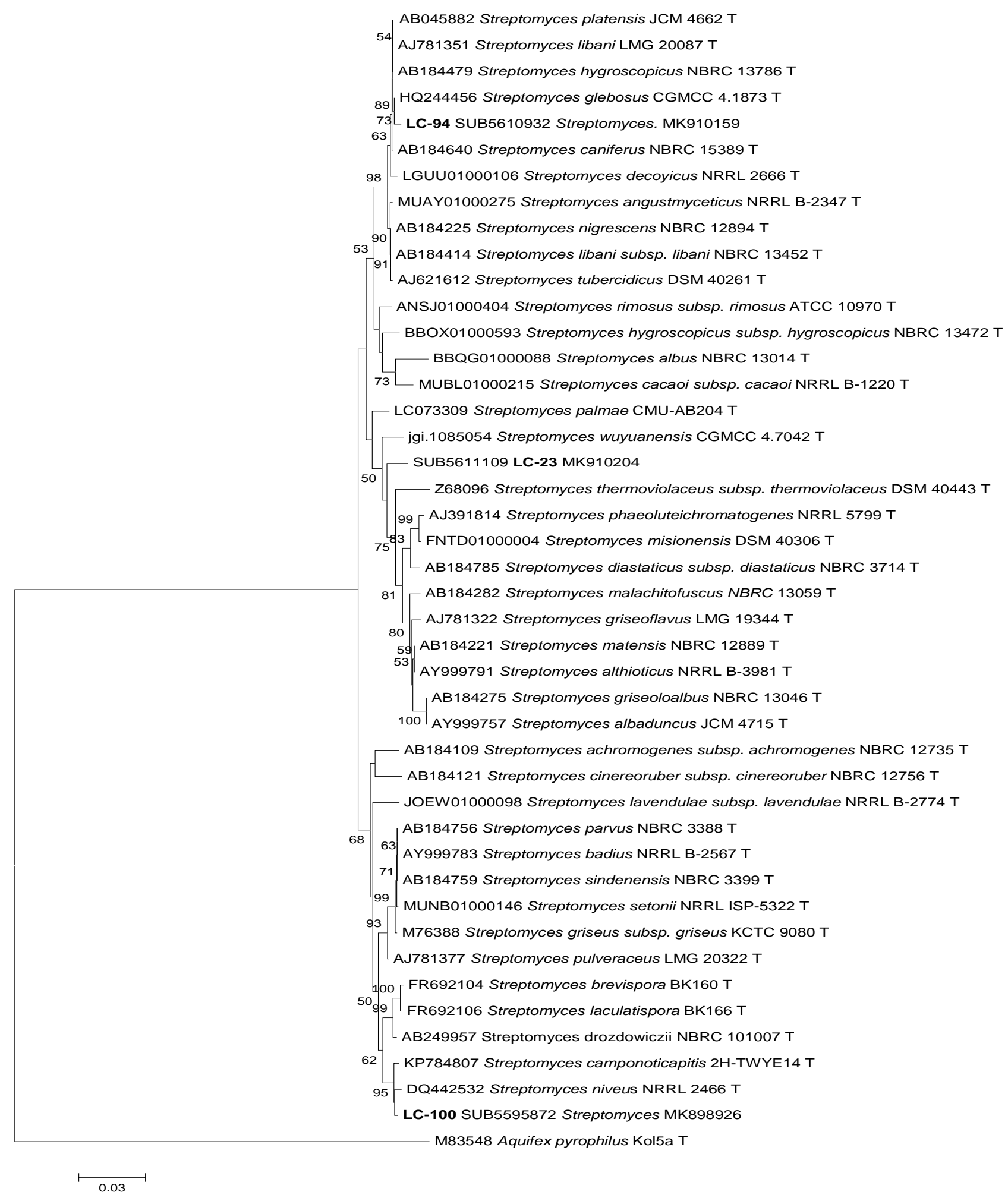

Figure 5. Phylogenetic tree constructed from 16S rRNA gene sequences of strain LC-23, LC-94, LC100, and the type strain in the genus of Streptomyces. 


\section{Discussion}

Actinomycetes was succesfully isolated from tree lichen in area of Cibinong Science Centre (CSC) and Cibodas Botanical Garden (CBG), West Java, Indonesia. Spread dilution method on three kinds of agar media; HV, YIM 6 and YIM 711 obtained 125 isolates of lichens-associated actinomycetes. The combination of dilution number $10^{-3}$ until $10^{-5}$ and selective medium more affected in isolation process than specific thallus of lichen used in this research. Parrot et al., (2015) isolated various actinomycetes from litoral lichens and declared that diversity of actinomycetes was most influenced by the selective media rather than lichen species or the level of lichen thallus association.

Seven genera of actinomycetes have been identified in this research; Actinoplanes, Amycolatopsis, Angustibacter, Kribbella, Micromonospora, Mycobacterium, and Streptomyces. Around $87 \%$ of the isolates belong to Streptomyces genera. Genus Streptomyces belongs to Streptomycetaceae family, in the classis of Actinobacteria and family Actinomycetales (Anderson and Wellington, 2001). Streptomyces species aerobic, most are able to torm extensively branched substrate mycelium and produce aerial hypae that typically differentiate into chains of spores (Kampfer et al., 2008).

Antimicrobial activity was showed by 24 isolates against at least one microbial tested; to Bacillus subtilis BTCC B.612, Escherichia coli BTCC B.614, Candida albicans BTCC Y.33, Staphylococcus aureus BTCC B.611, Micrococcus luteus BTCC B.552. The potential isolates against more than one microbial tested has been shown by LC-23, LC-94, and LC-100 that belongs to Streptomyces genera. The most important characteristic of Streptomyces is the ability to produce secondary metabolite with antibacterial, antifungal, and antitumoral properties (Hasani et al., 2014). Streptomyces produce $74 \%$ bioactive compound among another genera in Actinomycetes, and around $34 \%$ of all microbial metabolite (Berdy, 2005). Streptomyces species can be distinguished by many methods, such as molecular identification 16S rRNA (Hasani et al., 2014). Molecular identification 16S rRNA of LC-23 has $98.51 \%$ similarity with Streptomyces palmae, LC-94 has $99.86 \%$ similarity to
Streptomyces caniferus and LC-100 has 99.64\% similarity to Streptomyces camponoticapitis. Some characteristic of those closests species were different with the characteristics owned by each isolates. Neighbour joining phylogenetic tree showed different result for LC-94. The closest species for isolate LC-94 was Streptomyces glebosus with $99.78 \%$ homology to LC-23. Interesting result of LC-23 showed distinct phyletic line with other Streptomyces species as type strain. All the closest species showed by phylogenetic tree have smaller similiraty value compared to 16S rRNA identification result.

The boundary for species delineation in genus Streptomyces seems to be higher than 97\%. Identification 16S rRNA gene sequence data cannot serve as the sole basis for species delineation within the genus Streptomyces. Result of 'simple' treeing methods (the neighbour-joining method) should be regarded with caution, given that a tree is only a visual aid to place a novel species in its approximate neighbourhood (Kampfer and Labeda 2003). Berdy (2012) declared that only $\sim 1 \%$ actinobacteria were cultivable. It was the reason why finding the novel species of Actinomycetes still an interesting research activity as the source of antibiotic producer. Indonesia lichens-associated actinomycetes was never been reported before. The result of this research may become a source to find potential bioactive metabolite as a new antibiotic.

\section{Conclussion}

Actinomycetes was sucesfully isolated from lichens in the area of Cibinong Science Centre (CSC) and Cibodas Botanical Garden (CBG). Totaly 69 isolates were identified as the genera Actinoplanes, Amycolatopsis, Angustibacter, Kribbella, Micromonospora, Mycobacterium, and Streptomyces. The screening process showed 24 isolates has antimicrobial activity, with the highest inhibitory activity against Micrococcus luteus BTCC B.552.

\section{Acknowledgements}

The author is grateful for the support to Research Center for Biotechnology, Indonesian Institute of Sciences (LIPI) where the research conducted. 


\section{References}

Anderson A.S., Wellington E.M.H. (2001). The Taxonomy of Streptomyces and Related Genera. International Journal of Systematic and Evolutionary Microbiology, 51: 797-814.

Axenov-Gibanov D.V., Voytsekhovskaya I.V., Tokovenko B.T., Protasov E.S., Gamaiunov S.V., Rebets Y.V., Luzhetskyy A.N., Timofeyev M.A. (2016). Underground Lake and Moonmilk Speleothem from The Biggest Conglomeratic Karstic Cave in Siberia as Source of Novel Biologically Active Compounds. Plos One, 11 (2): 1-12.

Berdy J. (2005). Bioactive Microbial Metabolite A Personal Review. The Journal of Antibiotic, 58 (1): 1-26.

Berdy J. (2012). Thoughts and Facts About Antibiotics: Where We Are Now and Where We Are Heading. The Journal of Antibiotics, 65: 325-395.

Charousová I., Steinmetz H., Medo J., Javoreková, S., Wink J. (2016). Characterization of Antimycins-Producing Streptomycete Strain VY46 Isolated from Slovak Soil. Brazilian Archives of Biology and Technology, 59: 1-9.

Davies J., Wang T., Taylor K., Warabi X., Huang R.J. Andersen. (2005). Uncialamycin, A New Enediyne Antibiotic. Organic Letters 7 (23): 5233-5236.

Genniloud O., Gonzales I., Salazar O., Martin J., Tormo J.R., Vicente F. (2011). Current Approaches to Exploit Actinomycetes as a Source of Novel Natural Products. Journal Industries Microbiol Biotechnol, 38:375-389.

Gonzales I., Ayuso-Sacido A., Anderson A., Genniloud O. (2005). Actinomycetes Isolated from Lichen: Evaluation of Their Diversity and Detection of Biosynthetic Gene Sequences. FEMS Microbiology Ecology, 54:401-415

Grube, M. and Berg G. (2009). Microbial Consortia of Bacteria and Fungi with Focus on The Lichen Symbiosis. British Microbial Society, 23:72--85.

Hale, M.E. (1979). The Biology of Lichens. Victoria (GB): Edward Arnold. Hamada M., Yamamura H., Komukai C., Tamura T., Suzuki K.I., Hayakawa M. (2012). Luteimicrobium album sp. nov., a Novel Actinobacterium Isolated from a Lichen Collected in Japan, and Emended Description of The Genus Luteimicrobium. The Journal of antibiotics, 65(8):427-431.

Hasani A., Kariminik A., Issazadeh K. (2014). Streptomycetes: Characteristics and Their Antimicrobial Activities. International Journal of Advanced Biological and Biomedical Research, 2 (1): 63-75.
Hayakawa, M. (2008). Studies on The Isolation and Distribution of Rare Actinomycetes in Soil. Actinomycetologica, 22: 12-19.

Jiang Y., Wang X., Li G., Li Q., Liu C., Chen X., Wang L., Li Y., Jiang C. (2015). Diversity and Anti-Microbial Activities of Actinomycetes Associated with Three Species of Lichens. American Journal of Bioscience, 3(5): 171-177.

Jiang Y, Li Q, Chen X, Jiang C. 2016. Isolation and Cultivation Methods of Actinobacteria. http://dx.doi.org/10.5772/61457, 39-57.

Kampfer P., Labeda D.P. (2003). International Committee on Systematics of Prokaryotes Subcommittee on The Taxonomy of Streptomycetaceae. Minutes of The Meeting, 30 July 2002, Paris. France. Int.J.Syst.Evol Microbiol, 53: 925.

Kämpfer P., Huber B., Buczolits S., Thummes K., Grün-Wollny I., Busse H.J. (2008). Streptomyces specialis sp. nov. International Journal of Systematic and Evolutionary Microbiology, 58(11): 2602--2606.

Kim O.S., Cho Y-J., Lee K., Yoon S-H.Y., Kim M., Na H., Park S-C., Jeon Y.S., Lee J-H., Yi H., Won S., Chun J. (2012). Introducing EzTaxon-e: a Prokaryotic 16S rRNA Gene Sequence Database with Phylotypes that Represent Uncultured Species. International Journal of Systematic Evolutionary Microbioogy, 62 (3): 716-721.

Kumar N., Singh R.K., Mishra S.K., Singh A.K., Pachouri U.C. (2010). Isolation and Screening of Soil Actiomycetes as Source of Antibiotik Active Against Bacteria. International Journal of Microbiology Research, 2: 12-16.

Lazzarini A., Cavaletti L., Toppo G., Marinelli F. (2000). Rare Genere of Actinomycetes as Potential Producers of New Antibiotik. Antonie van Leeuwenhoek, 78: 399-405.

Li B., Xie C.H., Yokota A. (2007). Nocardioides exalbidus sp. nov., a Novel Actinomycete Isolated from Lichen in Izu-Oshima Island, Japan. Actinomycetologica, 21(1): 22-26.

Li Y., Ye L., Wang X., Zhao J., Ma Z.,Yan K., Xiang W., Liu C. (2016). Streptomyces camponoticapitis sp. nov., an Actinomycete Isolated from The Head of an Ant (Camponotus japonicus Mayr). International Journal of Systematic and Evolutionary Microbiology, 66 (10):3855-3859.

Liu C., Jiang Y., Wang X., Chen D., Chen X., Wang L., Han L., Huang X., Jiang C. (2017). Diversity, Antimicrobial Activity and Biosynthetic Potential of Cultivable Actinomycetes Associated with Lichen Symbiosis. Microbial ecology, 74(3):570-584.

Lisdiyanti P., Ratnakomala S., Ridwan R., Widyastuti Y., Otoguro M., Katsuhiko A. (2011). Ecological Study of Rare- 
Actinomycetes in Soils and Leaf-Litters. Annales Bogorienses, 15 (2): 31-36.

Madigan M.T., Martinko J.M., Stahl D.A., Clark D.P. (2012). Brock Biology of Microorganisms Thirteen Edition. Prentice-Hall, Inc. New Jersey.

Nash III, T.H. (2008). Lichen Biology. Cambridge University Press, New York.

Nimnoi P.N., Pongsilp, Lumyong S. (2009). Endophytic Actinomycetes Isolated from Aquilaria crasna Pierre ex Lec and Screening of Plant Growth Promoters Production. World Journal Microbiol Biotechnol, 26: 193-203.

Noviady I., Rivai R.R. (2015). Identifikasi Kondisi Kesehatan Pohon Peneduh di Kawasan Ecopark, Cibinong Science Centre-Botanic Gardens; Prosiding of Seminar Nasional Masyarakat Biodiveritas Indonesia, Bandung, 13 June 2015. [Indonesia].

Okoro C.K., Brown R., Jones A.L., Andrews B.A., Asenjo J.A., Goodfellow M., Bull A.T. (2009). Diversity of Culturable Actinomycetes in Hyper-Arid Soils of The Atacama Desert, Chile. Antonie Van Leeuwenhoek, 95(2): 121133.

Parrot D., Antony-Babu S., Intertaglia L., Grube M., Tomasi S., Suzuki M.T. (2015). Litoral Lichens as a Novel Cource of Potentially Bioactive Actinobacteria. Scientific Report, 5: 1-14.

Pérez M., Schleissner C., Fernández F., Rodríguez P., Reyes F., Zuñiga P., De La Calle F., Cuevas C. (2016). PM100117 and PM100118, New Antitumor Macrolides Produced by a Marine Streptomyces caniferus GUA-06-05-006A. The Journal of Antibiotics, 69(5): 388.

Pimentel-Elardo S.M., Kozytska S., Bugni T.S., Ireland C.M., Moll H., Hentschel U. (2010). Anti-Parasitic Compounds from Streptomyces sp. Strains Isolated from Mediterranean Sponges. Marine Drugs, 8(2): 373-380.

Pratiwi R.H., Hidayat I., Hanafi M., Mangunwardoyo W. Antibacterial Compound Produced by Pseudomonas aeruginosa Strain UICC B-40, an Endophytic Bacterium Isolated from Neesia aitissima. 2017. Journal of Microbiology, 55 (1): 289-295.

Ratnakomala S., Lisdiyanti P., Prayitno N.R., Triana E., Lestari Y., Hastuti R.D., Otoguro M., Widyastuti Y., Ando K., Sukara E. (2016). Diversity of Actinomycetes from Eka Karya Botanical Garden Bali. Biotropia 23(1): 42 - 51

Rosyunita. (2017). Eksplorasi Liken Parmotrema dan Usnea Sebagai Pewarna dan Penghasil
Senyawa Antibakteri di Kebun Raya Cibodas Kabupaten Cianjur Jawa Barat. [Thesis]. Institut Pertanian Bogor, Bogor. [Indonesian].

Sacramento D.R, Coelho R.R., Wigg, M.D., Linhares, L.F.D.T.L., dos Santos M.G.M., Semêdo L.T.D.A.S., da Silva A.J.R. (2004). Antimicrobial and Antiviral Activities of an Actinomycete (Streptomyces sp.) Isolated from a Brazilian Tropical Forest Soil. World Journal of Microbiology and Biotechnology, 20(3): 225229.

Subramani, R., Aalbersberg, W. (2012). Marine Actinomycetes: an Ongoing Source of Novel Bioactive Metabolites. Microbiological research, 167(10): 571-580.

Sujarit K., Kudo T., Ohkuma M., Pathom-Aree W., Lumyong S. (2016). Streptomyces Palmae sp. nov., Isolated from Oil Palm (Elaeis guineensis) Rhizosphere Soil. International Journal of Systematic and Evolutionary Microbiology, 66(10): 3983--3988.

Suneetha V., Raj K. (2011). Isolation and Identification of Streptomyces ST1 and ST2 Strains from Tsunami Affected Soils: Morphological and Biochemical Studies. Journal of Oceanography and Marine Science 2(4): 96--101.

Strain, M.C., (1986). Validation of The Publication of New Names and New Combinations Previously Effectively Published Outside the I JSB. International Journal of Systematic Bacteriology, 573-576.

Tamura K., Stecher G., Peterson D., Filipski A., Sudhir K. (2013). MEGA6: Molecular Evolutionary Genetics Analysis Version 6.0. Molecular biology and evolution 30 (12): 27252729.

Tang, S.K., Wang Y., Guan T.W., Lee J.C., Kim C.J., Li, W.J. (2010) . Amycolatopsis halophila sp. nov., a Halophilic Actinomycete Isolated from a Salt Lake. International Journal of Systematic and Evolutionary Microbiology, 60(5): 1073-1078.

Widyastuti and Ando. (2010). Taxonomic and Ecological Studies of Fungi and Actinomycetes in Indonesia. Joint Research Project Between Indonesian Institute of Science (LIPI) Representing The Government Research Centre (GRC) of The Republic of Indonesia and National Institute of Technology and Evaluation (NITE) of Japan. 